\title{
Experiencing Life, Exploring Content, Broadening Forms: An Empirical Research on the Art Education of Life in Rural Kindergartens
}

\section{Tao Dan}

Affiliation: Yuqian Town Central Kindergarten, Lin'an District, Hangzhou 310000, Zhejiang, China

Address: Yuqian Town Central Kindergarten, Lin'an District, Hangzhou 310000, Zhejiang, China.

Correspondence to: Tao Dan, E-mail: $970332011 @ q q . c o m$

DOI: https://doi.org/10.15354/sief.21.s1.ab044

The authors declare no competing interest.

According to Xingzhi Tao, education should focus on life, life determines education, and then education remakes life, the role of education can only be played through life. Art comes from life, it is the way that children experience the world perceptually and also the other language to express their understanding of the world. However, with the development of Arts education, existing problems are gradually revealed. Based on the analysis of current Arts activities, the research was carried out on the following issues that children don't have the effective experience before Art activities; the content of Art activities doesn't conform to the children's experience and life in the teaching process; the teaching form and materials are single and children lack interest problems, etc. By observing and experiencing life, the children can accumulate perceptual experience. By following the children's experiences and life, we can explore the teaching content. By broadening the forms and materials of art activities, the children are glad to perform, which will improve children's life observation and aesthetic ability, stimulate children's creative interest being willing to create and performance, improve the ability of teachers' observation, curriculum producing and teaching skills and it also explores the use of art teaching method and life-oriented materials in rural kindergartens.

\section{Keywords}

Lifestyle, Arts Activity, Experience Perception

Science Insights Education Frontiers, 2021 September 13; Vol. 10, Suppl. 1, pp.14.

(C) 2021 Insights Publisher. All rights reserved.

Creative Commons Non Commercial CC BY-NC: This article is distributed under the terms of the Creative Commons Attribution-NonCommercial 4.0 License which permits non-commercial use, reproduction and distribution of the work without further permission provided the original work is attributed by the Insights Publisher. 